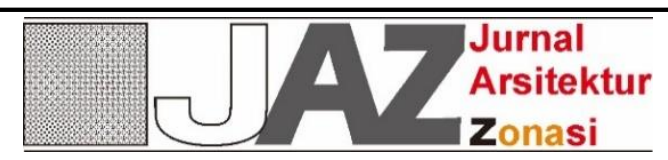

http://ejournal.upi.edu/index.php/jaz - e-mail: jurnal.zonasi@gmail.com dan jurnal_zonasi@upi.edu doi.org/10.17509/jaz.v3i3.25927

\title{
KONSERVASI LAHAN RAWAN LONGSOR DI RW 9 KELURAHAN SRONDOL KULON, KECAMATAN BANYUMANIK, SEMARANG
}

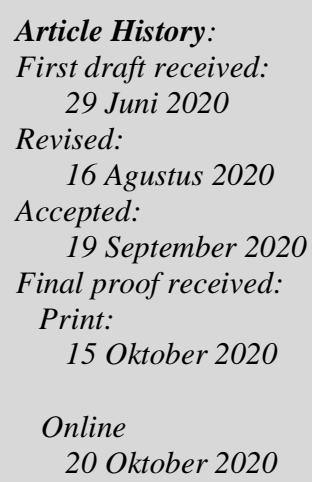

Jurnal Arsitektur ZONASI is indexed and listed in several databases:

SINTA 4 (Arjuna)

GARUDA (Garda Rujukan Digital) Google Scholar

Dimensions oneSearch

BASE

Member:
Crossref
RJI
APTARI
FJA (Forum Jurna Arsitektur)
IAI
AJPKM

Member:

Crossref

AJPKM

\author{
Rina Kurniati ${ }^{1}$ \\ Wakhidah Kurniawati ${ }^{2}$ \\ Diah Intan Kusumo Dewi ${ }^{3}$ \\ Nur Azizah Ferawati ${ }^{4}$ \\ Email: adalerina_66@yahoo.com \\ wakhidahkurniawati@lecturer.undip.ac.id \\ diah.intan@gmail.com \\ nur.azizah20@pwk.undip.ac.id
}

1,2,3,4 Urban and Regional Planning, Faculty Engineering, Diponegoro University

Jl. Prof. Sudarto No.13, Tembalang, Kec. Tembalang, Kota Semarang, Jawa Tengah 50275

Abstract: Srondol Kulon is an urban-village in the South of Semarang City. Located in the Kaligarang watershed with hilly characteristics makes the area vulnerable to landslides. In addition, land use change from forests to settlements increases the risk of landslides. $R W 9$ is one of the area of Srondol Kulon which traversed by the regional fault of Semarang City and making this area very vulnerable to land movement. The houses in $R W 9$ generally have a pavement yard so the rainwater absorption area is very limited. This phenomenon will have an impact on the slope stability so that if there is land movement, it will cause disaster. On the other hand, the community does not yet understand the importance of land conservation in landslide prone areas. It is necessary to educate the community about the importance of land conservation in landslide-prone areas so that they can be more concerned about protecting their residential environment. This journal will discuss the potential and problems of physical conditions possessed by $R W 9$ so that the authors can recommend land conservation measures to conserve land to the community. The results of this study will be made in the form of a conservation manual that is easily understood by the people in RW 9 so that they can implement effective land conservation methods to prevent landslides.

\section{Keywords: Community Service, Landslide Disaster, Land Conservation}

Abstrak: Srondol Kulon adalah salah satu kelurahan di sebelah Selatan Kota Semarang. Terletak di DAS Kaligarang dengan karakteristik perbukitan membuat wilayah tersebut rentan terkena bencana tanah longsor. Selain itu, perubahan tata guna lahan dari hutan ke pemukiman memperbesar resiko terjadinya longsor. Salah satu wilayahnya, yaitu RW 9 Kelurahan Srondol Kulon dilalui oleh sesar regional Kota Semarang sehingga menjadikan kawasan ini sangat rentan terhadap pergerakan tanah. Keberadaan perumahan dengan tutupan lahan menggunakan perkerasan akan berdampak pada stabilitas lereng sehingga apabila terjadi pergerakan tanah dapat menimbulkan bencana. Di sisi lain, masyarakat belum memahami arti penting konservasi lahan pada kawasan rawan longsor. Oleh karena itu, perlu mengedukasi masyarakat tentang pentingnya konservasi lahan pada kawasan rawan longsor agar mereka dapat lebih peduli untuk menjaga lingkungan permukiman mereka. Pada jurnal ini akan dibahas mengenai potensi dan permasalahan kondisi fisik yang dimiliki oleh RW 9 Kelurahan sehingga dapat merekomendasikan langkah konservasi lahan yang memungkinkan dilakukan oleh masyarakat. Hasil dari penelitian ini akan dibuat dalam bentuk buku panduan konservasi yang mudah dipahami oleh masyarakat di RW 9 sehingga mereka dapat menerapkan cara konservasi lahan yang efektif untuk mencegah longsor.

Kata Kunci: Pengabdian Masyarakat, Bencana Longsor, Konservasi lahan 


\section{Pendahuluan}

Tanah longsor merupakan bagian dari gerakan tanah (Zakaria, 2009), yaitu luncuran atau gelinciran masa batuan dari atas lereng ke bawah atau ke luar lereng (Sharpe, 1938). Tanah longsor pada umumnya bersifat lokal, serta terjadi di wilayah yang memiliki karakteristik topografi berbukit dengan kemiringan lereng yang landai maupun terjal (Arifianti, 2011). Fenomena tanah longsor dapat dikategorikan sebagai bencana alam apabila menimbulkan kerugian, baik berupa materil maupun korban jiwa. Oleh karenanya, wilayah permukiman serta daerah terbangun yang terletak pada wilayah dengan kemiringan tertentu beresiko terkena bencana tanah longsor.

Beberapa kota di Indonesia beresiko mengalami bencana tanah longsor. Salah satu kota yang memiliki resiko bencana tanah longsor adalah Kota Semarang. Di dalam dokumen RTRW Kota Semarang tahun 20112031, wilayah bagian Selatan dan Barat Kota Semarang (Kecamatan Banyumanik, Tembalang, Gunungpati, Gajah Mungkur dan Semarang Barat) merupakan daerah rawan longsor (Pemerintah Kota Semarang, 2011). Kelurahan Srondol Kulon menjadi salah satu kelurahan di bagian Selatan Kota Semarang yang beberapa kali mengalami bencana longsor. Dari segi geografis, Kelurahan Srondol Kulon terletak pada kemiringan yang sangat curam terutama di bagian Barat, yang berbatasan langsung dengan Ke camatan Gunungpati (Kelompok 4B Proses Perencanaan, 2014). Perubahan tata guna lahan dari kawasan hijau menjadi kawasan terbangun turut mempengaruhi peningkatan zona rawan dan kejadian gerakan tanah di kelurahan tersebut (SNI, 8291:2016). Selain itu berkurangnya jenis tanaman yang mampu menahan air, terjadinya penebangan pohon tanpa adanya penggantian yang memadai (Utami, Tjahjono, \& Sriyono, 2017), kondisi jaringan drainase yang kurang memadai juga menjadi salah satu akibat kerentanaan gerakan tanah di Kelurahan Srondol Kulon.

Menurut Erfandi (2013), salah satu penyebab longsor pada lahan berlereng adalah sistem pengelolaan lahan yang tidak memperhatikan kaidah konservasi tanah. Selain itu, luas kawasan hijau yang tidak seimbang dengan luas wilayah Daerah Aliran Sungai (DAS) serta pemanfaatan ruang yang tidak sesuai dengan peruntukannya memperparah resiko terjadinya bencana longsor (Prihambodo, 2017). Dalam upaya peningkatan kualitas lahan pada kawasan permukiman yang rawan bencana, dirasa perlu untuk melakukan konservasi kawasan permukiman. Konservasi disini merupakan penggunaan lahan sesuai dengan daya guna dan kemampuan lahan, serta memelihara dan mempertahankan produktifitasnya (Ismayani, 2018). Tujuan dari konservasi adalah untuk mencegah kerusakan tanah, memperbaiki kerusakan tanah dan memelihara serta meningkatkan produktivitas tanah, sehingga dapat menurunkan resiko terjadinya bencana longsor (Indrayati, 2013).

RW 9 kelurahan Srondol Kulon menjadi lokasi percontohan konservasi karena topografi wilayahnya curam (kemiringan antara 25-45\%) serta dilintasi oleh sesar regional Kota Semarang, sehingga paling rentan terhadap bencana longsor. Langkah konservasi ini dilakukan dengan mengidentifikasi potensi dan masalah yang berkaitan dengan kondisi fisik RW 9 Kelurahan Srondol Kulon. Selanjutnya, dijabarkan mengenai langkah-langkah konservasi yang memungkinkan untuk di implementasikan oleh masyarakat setempat.

\section{Teori Konservasi Lahan}

Konservasi lahan atau konservasi tanah merupakan upaya manusia untuk memperbaiki, meningkatkan dan mempertahankan kondisi lahan agar dapat berfungsi secara optimal, baik sebagai unsur produksi, media pengatur tata air maupun sebagai unsur perlindungan alam dan lingkungan (RRL,[1993] dalam Nugraha, RI, \& Utomowati, 2013). Dalam konteks bencana longsor, konservasi lahan berfungsi sebagai tindakan preventif untuk mencegah terjadinya longsoran. Longsoran ini terjadi karena banyak faktor, misalnya kemiringan lereng, jenis tanah, curah hujan, tata guna lahan serta faktor-faktor lain yang membuat lereng tidak stabil. Konservasi merupakan bagian dari upaya untuk menstabilisasi tebing (Erfandi, 2013), melalui penyesuaian tata guna lahan sesuai dengan resiko terjadinya longsor.

Metode konservasi dibedakan menjadi 3 golongan yaitu metode vegetatif, mekanis, dan kimia. Akan tetapi, konservasi dengan metode kimia tidak terlalu dibahas dalam konteks kebencanaan, sehingga penelitian ini berfokus pada konservasi vegetatif serta konservasi mekanik.

\subsection{Konservasi Mekanis}

Konservasi mekanis yaitu langkah konservasi melalui ilmu mekanis serta pembuatan konstruksi sebagai upaya pencegahan longsor. Konservasi mekanis menggunakan ilmu sipil seperti pembuatan teras sering, bangunan penahan, drainase, serta bangunan tutupan lahan lainnya, untuk mencegah terjadinya 
longsor (Wahyudi, 2014). Sedangkan menurut departemen pertanian (2004), pendekatan mekanis pengendalian longsor meliputi pembuatan saluran drainase, pembuatan bangunan penahan longsor, bangunan penguat dinding atau pengaman jurang, serta pembuatan trap-trap terasering.

\section{a. Teras}

Teras merupakan metode konservasi dengan cara memotong panjang lereng membentuk bangunan menyerupai tangga. Konstruksi teras ini berfungsi untuk menahan air sehingga mengurangi kecepatan dan jumlah aliran permukaan, serta memperbesar peluang penyerapan air oleh tanah (Dariah, Haryati, \& Budhyastoro, 2004). Pembuatan teras secara mekanis dapat menggunakan bahan-bahan, seperti tembok, batu, kawat brojong, kayu log, karung, serta jerami (Wahyudi, 2014). Jenis konstruksi dapat dipilih sesuai dengan tekanan lereng. Jika tekanan lereng sangat besar, maka konstruksi dengan material tembok sangatlah tepat. Sedangkan apabila tekanan lereng tidak terlalu besar, maka dapat menggunakan material seperti karung maupun jerami.

b. Drainase

Tujuan pembuatan saluran drainase adalah untuk mencegah genangan di permukaan tanah, sehingga air dapat mengalir tanpa merusak tanah (Dariah et al., 2004). Ketika terjadi hujan lebat, volume air melimpah sehingga perlu disalurkan ke lokasi penampungan atau pembuangan yang aman (Wahyudi, 2014). Menurut Masaki (1995) dalam (Risdiyanto, 2011), terdapat tiga macam tipe drainase, yaitu saluran terbuka, saluran tertutup serta gorong-gorong.

\subsection{Konservasi Vegetatif}

Konservasi vegetatif merupakan upaya konservasi tanah rawan longsor dengan menggunakan akar tanaman sebagai penghambat aliran permukaan serta untuk mencegah kerusakan struktur tanah. Peran vegetasi dalam mencegah longsor serta menstabilisasi lereng ditentukan oleh bentuk sistem perakaran (tunggang-serabut), tingkat kedalaman akar (dangkal-dalam), sebaran perakaran, susunan akar (berat akar per satuan volume akar) serta kekuatan akar (Atmojo, 2008). Sedangkan menurut (Erfandi, 2013), jenis tanaman yang cocok untuk mengurangi resiko erosi adalah tanaman dengan kerapatan tinggi, misalnya rumputrumputan yang kerapatan akarnya mencapai $1.040 .000 \mathrm{~cm} / \mathrm{cm}^{3}$ (Erfandi, 2013). Meskipun demikian, peran perakaran pohon dalam menanggulangi erosi ditentukan oleh umur tanaman, total panjang akar, diameter akar, serta kandungan liganin perakaran (Atmojo, 2008). Menurut Hairiah et al (2007) dalam (Atmojo, 2008), menyebutkan bahwa strategi yang paling tepat untuk mencegah erosi tebing adalah dengan menanam tanaman yang beragam dalam suatu lahan untuk meningkatkan jaringan akar yang kuat baik pada lapisan tanah atas maupun bawah.

Jenis tanaman yang dianjurkan untuk konservasi secara vegetatif adalah jenis tanaman yang cepat tumbuh, tanaman penutup, maupun dengan memelihara tanaman yang sudah ada/tumbuh liar di area tersebut (Wahyudi, 2014)). Jenis tanaman akar dalam yang dapat dipilih diantaranya adalah sonokeling, akar wangi, flemingia, kayu manis, kemiri, cengkeh, pala, petai, jengkol, melinjo, alpukat, kakao, kopi, teh, dan kelengkeng (Idjudin, 2011). Penanaman tanaman harus mengikuti pola tertentu seperti strip cropping, multiple cropping, agroforestry, pemanfaatan sisa tanaman serta penanaman pada saluran pembuangan atau grassed water ways (Wahyudi, 2014). Sedangkan tanaman untuk lapisan atas/tanaman penutup pada umumnya adalah jenis legum menjalar yang ditanam di antara tanaman tahunan, secara bergilir dengan tanaman semusim atau tanaman tahunan dan sebagai tanaman pemula (pionir) untuk rehabilitasi lahan kritis (Idjudin, 2011).

Kedua teknik konservasi yang telah disebutkan dapat dikombinasikan secara bersama. Sedangkan menurut (Dariah et al., 2004), meskipun tindakan konservasi vegetatif menjadi pilihan utama, namun perlakuan fisik mekanis seperti pembuatan saluran pembuangan air (SPA) atau bangunan terjunan masih tetap diperlukan untuk mengalirkan sisa aliran permukaan yang tidak terserap oleh tanah. Pada kondisi yang sangat parah, pendekatan mekanis seringkali bersifat mutlak jika pendekatan vegetatif saja tidak cukup memadai untuk menanggulangi longsor (Idjudin, 2011). Untuk melakukan perbaikan (konservasi) lahan kritis, terutama yang berada pada daerah yang mempunyai kelerengan, bangunan teknik sipil sebaiknya didahulukan dibuat, menyusul teknik konservasi vegetatif (Wahyudi, 2014).

\section{Metode Pengabdian}

Kegiatan pengabdian ini dilakukan dengan memberikan buku seta poster yang berisi panduan konservasi lahan rawan longsor. Untuk membuat panduan tersebut, dibutuhkan pemetaan potensi dan masalah pada aspek fisik, sehingga dapat memberikan rekomendasi konservasi lahan yang tepat bagi 
masyarakat di RW 9. Pengabdian ini dilaksanakan bertepatan dengan pandemik Covid-19, sehingga pengumpulan data yang tadinya melalui FGD dan Workshop dialihkan dengan mengumpulkan data-data sekunder serta melakukan survey digital melalui google street view. Karakteristik fisik yang diperhatikan yaitu kemiringan lereng rata-rata, jenis tutupan, karakteristik permukiman serta kondisi jalan dan drainase.

\section{Hasil dan Pembahasan}

\subsection{Kondisi Fisik RW 9 Kelurahan Srondol Kulon}

RW 9 terletak di sebelah Barat Kelurahan Srondol Kulon serta berbatasan langsung dengan sungai Kali Garang. Luas wilayah RW 9 mencapai $416.288 \mathrm{~m}^{2}$. Hampir seluruh wilayah di RW 9 memiliki kelerengan $2 \%$ hingga $40 \%$, serta memiliki ketinggian berkisar antara 99 hingga 243 mdpl. Berdasarkan profil geologis tersebut, RW 9 termasuk wilayah yang rawan terjadi longsor. Upaya konservasi lahan perlu dilakukan sebagai tindakan preventif untuk mencegah terjadinya longsor.

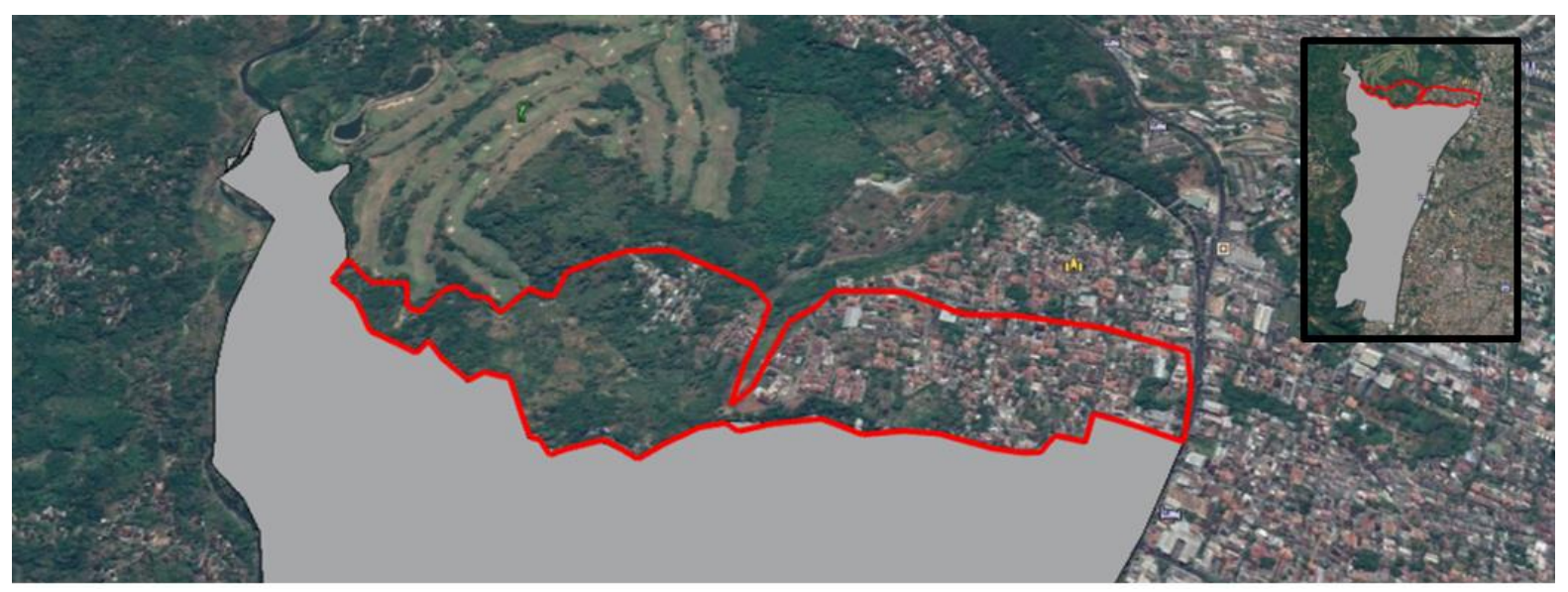

Gambar 1. Deliniasi RW 9, Kelurahan Srondol Kulon

Pemetaan potensi masalah pada aspek fisik diantaranya yaitu Karakteristik Tata Letak Permukiman, Kondisi Tutupan Lahan, serta Kondisi Drainase, yang dijabarkan sebagai berikut:

\section{a. Kondisi Lereng}

Beberapa lokasi di RW 9 memiliki perbedaan ketinggian yang cukup besar. Menurut Wahyudi (2014), tindakan yang efektif untuk mengantisipasi terjadinya erosi pada ketinggian yang besar adalah dengan membangun terasering ataupun membangun dinding penahan. Sedangkan langkah konservasi vegetatif dapat dilakukan setelah pembangunan dinding penahan tersebut selesai. Di beberapa lokasi di RW 9 sebenarnya telah dibangun dinding penahan, seperti misalnya di Jalan Bukit Permata Raya. Diding penahan tersebut terbuat dari batu-batu yang di semen serta berbentuk terasering, sehingga mengurangi kemiringan dinding. Dinding tersebut juga telah dilengkapi dengan saluran drainase, sehingga air hujan tidak akan terkumpul ke dalam satu bagian dinding serta mempercepat pengeringan.

Walaupun beberapa lokasi dengan kemiringan yang curam telah dibuat dinding penahan, akan tetapi di beberapa rumah dengan posisi lereng berada di bagian belakang rumah, tidak dilengkapi dengan dinding penahan sehingga apabila terjadi hujan lebat, resiko terjadi longsoran cukup besar. Sebagai contoh, pada tanggal 20 Februari 2020 terjadi bencana longsor yang menimpa tiga rumah di Pasansari RT 4/RW 9 Kelurahan Srondol Kulon. Ketiga rumah tersebut berlokasi di lahan yang tidak diperkuat dengan talud sebagai pondasi, sehingga bagian belakang rumah tersebut tergerus oleh longsor (Widiyanto, 2020). 


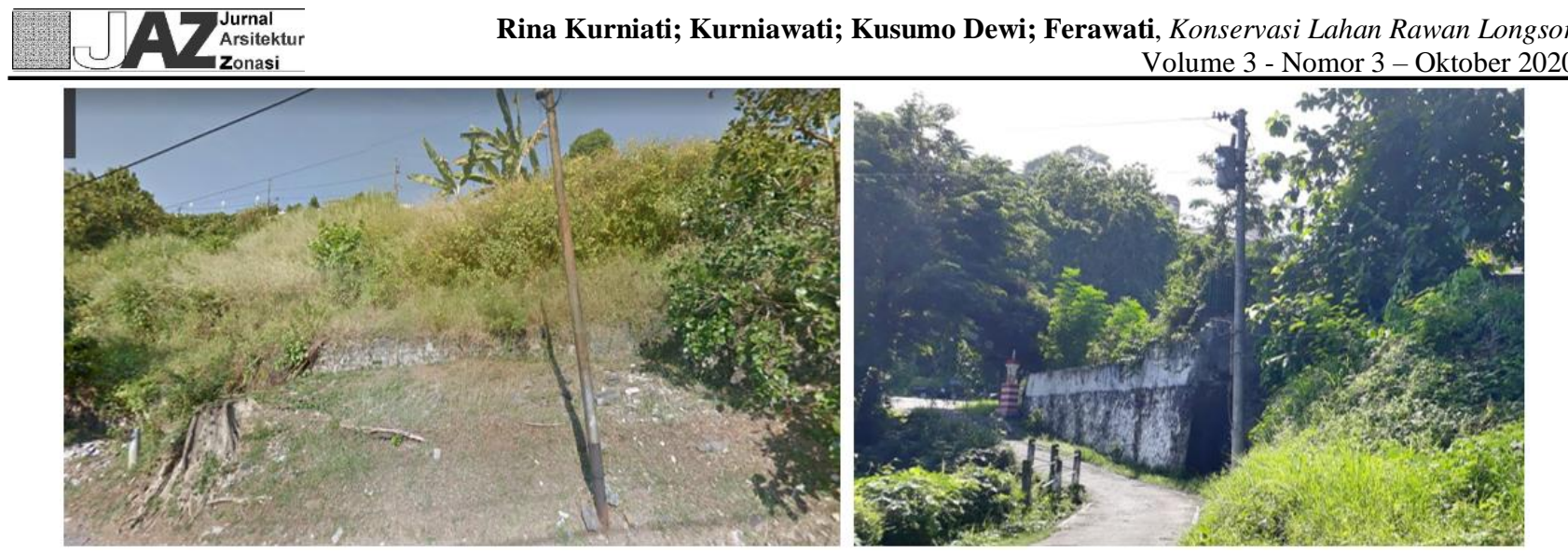

Gambar 2. Kondisi Lereng di Jalan Bukit Permata Raya

\section{b. Kondisi Permukiman}

Pola permukiman di RW 9 pada umumnya mengikuti bentuk jaringan jalan. Akan tetapi tidak terlalu terlihat perbedaan ketinggian yang mencolok antara jarak satu rumah dengan rumah yang lainnya, sehingga hampir tidak ada perumahan yang berbentuk terasering. Perumahan yang berada di Jalan Ngesrep Barat III pada umumnya memiliki halaman rumah yang berplester serta tidak memiliki vegetasi atau pohon sebagai daerah resapan, sehingga air hujan tidak bisa masuk langsung ke tanah. Pada daerah ini, air hujan langsung dialirkan ke saluran drainase.

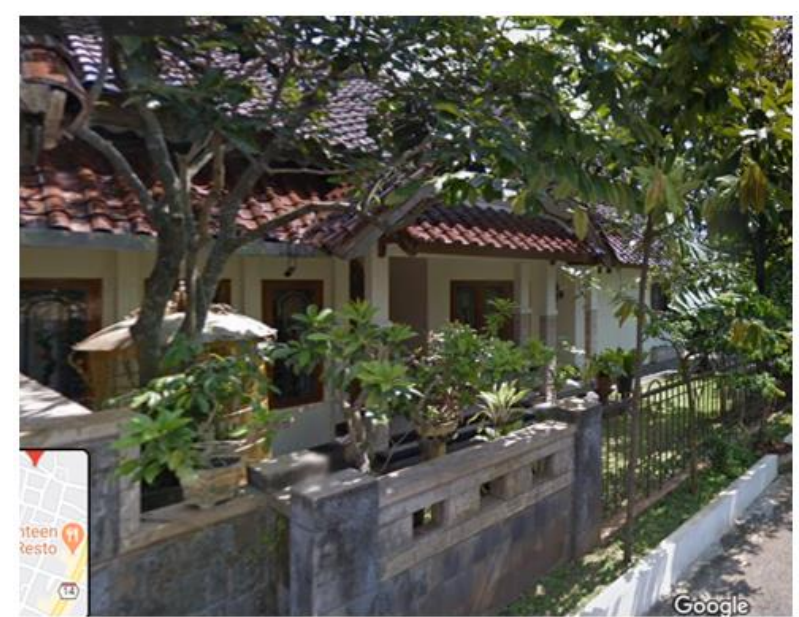

(a)

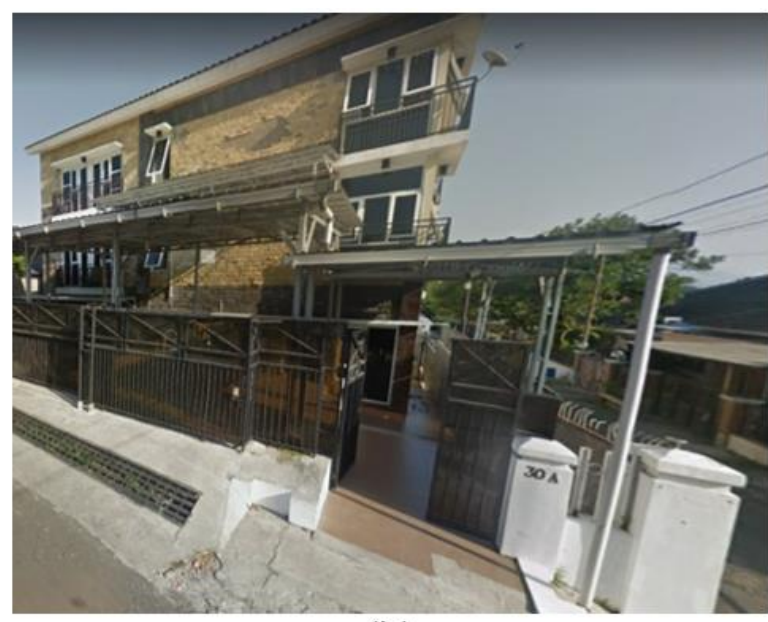

(b)

Gambar 3. Kondisi Perumahan di (a) Jalan Ngesrep Barat III, dan (b) Jalan Bukit Permata

Kondisi perumahan sedikit berbeda di daerah perumahan sebelah Barat RW 9, termasuk perumahanperumahan di Jalan Tanah Putih dan Bukit Permata. Perumahan yang berada di Barat ini rata-rata memiliki halaman yang tidak di plester, serta rata-rata telah ditanami vegetasi, baik vegetasi berakar dangkal maupun dalam. Penanaman vegetasi tersebut tentunya dapat meningkatan resapan air ke tanah, sehingga minim terjadi genangan atau limpasan.

\section{c. Tutupan Lahan}

Perbandingan penggunaan lahan permukiman dengan perkebunan atau hutan rata-rata adalah 50:50. Kawasan permukiman berada di bagian Timur sedangkan lahan perkebunan dan hutan berada di wilayah bagian Barat RW 9. Berdasarkan data yang diperoleh, wilayah permukiman minim Ruang Terbuka Hijau (RTH). Hal ini disebabkan karena tingginya kepadatan bangunan rumah, serta halaman rumah di wilayah tersebut pada umumnya di plester sehingga tidak bisa ditanami oleh vegetasi. Akan tetapi, di beberapa wilayah permukiman, masih terdapat beberapa lahan gundunl yang sebenarnya bisa ditanami oleh vegetasi berakar dangkal maupun dalam. Contohnya pada gambar 4 yang merupakan salah satu lahan di Bukit Permata Raya. 


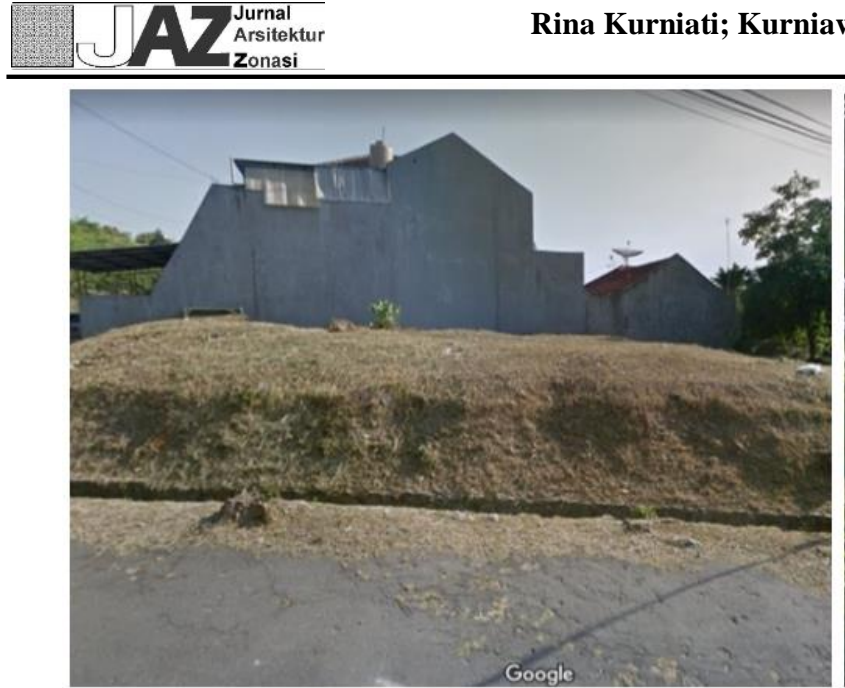

(a)

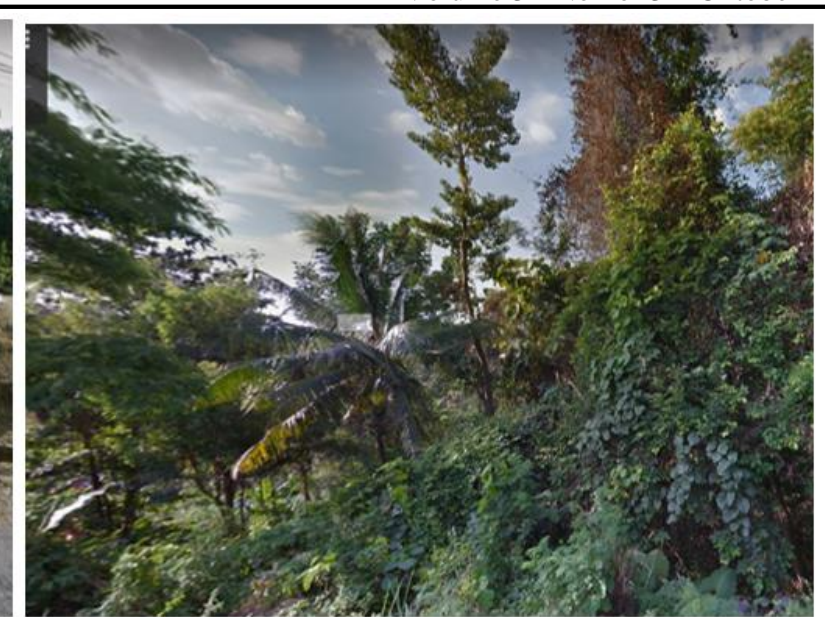

(b)

Gambar 4. Tutupan Lahan di (a) perumahan Bukit Permata Raya dan (b) Wilayah perkebunan dan hutan

Tata guna lahan di wilayah bagian Barat RW 9 pada umumnya merupakan perkebunan maupun hutan. Vegetasi yang tumbuh di daerah tersebut beragam, mulai dari trembesi, palem, hingga jati sebagai vegetasi berakar dalam, serta rumput-rumputan menjalar sebagai vegetasi berakar dangkal. Pada daerah ini, resapan air cukup besar, sehingga minim resiko terjadi longsor.

\section{d. Kondisi Drainase}

Hampir seluruh wilayah di RW 9 telah memiliki saluran drainase dengan kondisi yang cukup beragam. Beberapa saluran drainase di Jalan Tanah Putih II mengalami sedimentasi serta ditumbuhi vegetasi, sehingga memerlukan pengerukan agar aliran air lancar. Di Jalan Bukit Permata Raya, saluran drainase dibangun pada tembok-tembok pengaman serta di samping-samping jalan. Terdapat beberapa saluran drainase yang memotong jalan serta membentuk aliran dari wilayah atas ke wilayah dibawahnya. Beberapa saluran drainase dibangun tertutup, sedangkan beberapa saluran drainase terbuka, secara alami tertutupi oleh sedimentasi serta vegetasi.

Di beberapa jalan yang menjadi penghubung antara satu wilayah permukiman dengan wilayah lainnya tidak dilengkapi dengan saluran drainase (Gambar 5). Selain itu di samping jalan terdapat perbedaan ketinggian tanah yang tidak dilengkapi dengan dinding penahan, sehingga memiliki resiko terjadi erosi yang cukup tinggi.
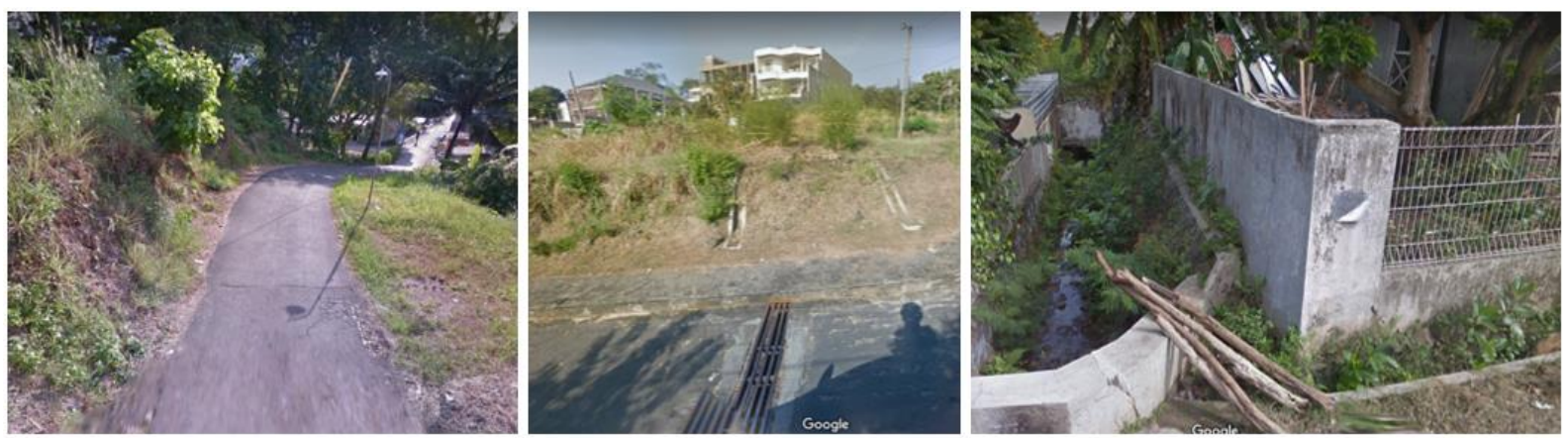

Gambar 5. Kondisi Saluran Drainase di beberapa lokasi di RW 9

\subsection{Upaya Konservasi di RW 9 Kelurahan Srondol Kulon}

Berdasarkan kondisi fisik pada RW 9 Kelurahan Srondol Kulon, terdapat permasalahan berupa kurangnya daerah resapan, terdapat lereng terjal yang belum bertalut dan sedimentasi drainase. Sebagai upaya konservasi, kawasan RW 9 akan dibagi persegmen wilayah. Berikut dibawah ini segmen wilayah konservasi di RW 9 Kelurahan Srondol Kulon. 


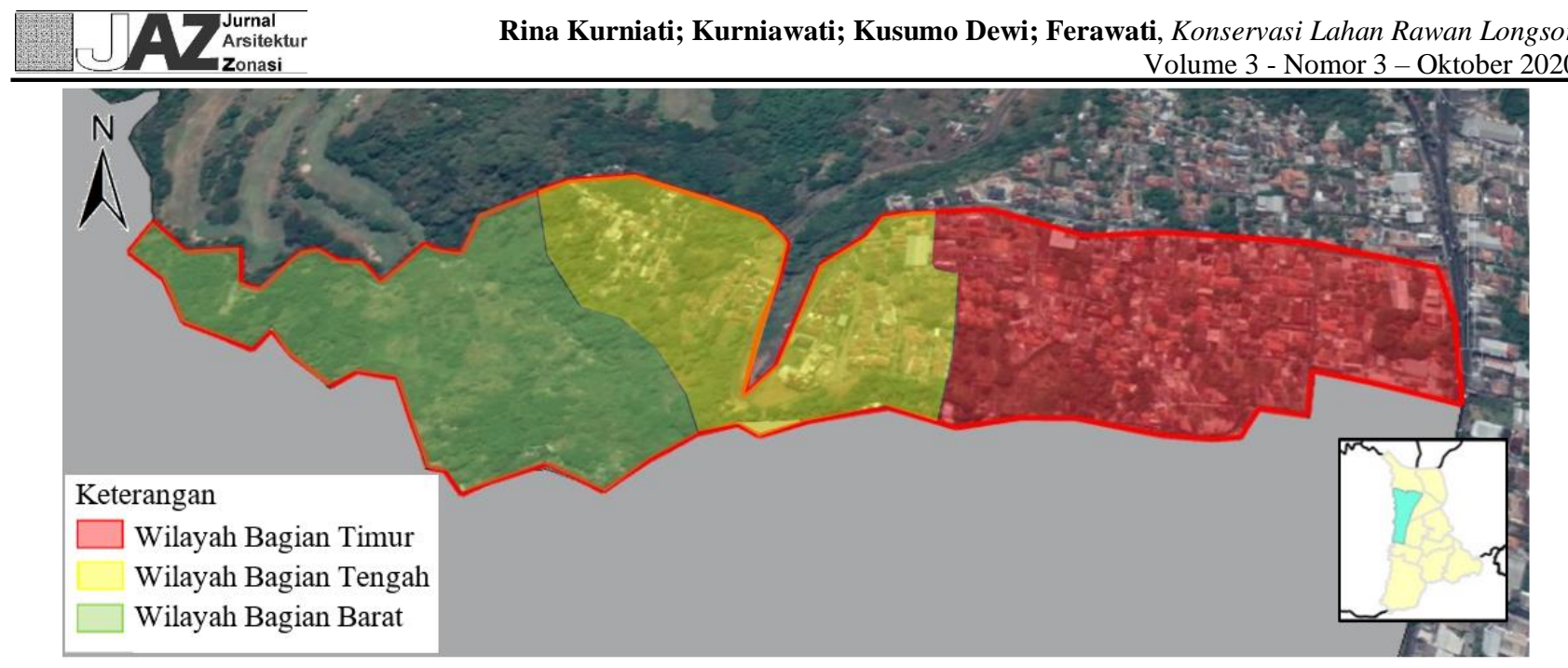

Gambar 6. Pembagian Wilayah Konservasi di RW 9 Kelurahan Srondol Kulon

\section{a) Wilayah bagian Timur}

Wilayah bagian Timur merupakan wilayah dengan ketinggian tertinggi di RW 9 serta berperan penting sebagai daerah resapan air hujan. Daerah resapan ini berfungsi untuk meresapkan air hujan ke tanah sehingga mengurangi aliran air di permukaan tanah. Kurangnya daerah resapan mengakibatkan banyaknya aliran air dari wilayah atas ke wilayah di bawahnya (Bukit Indah Regency, dan Plasansari) dan akan mengganggu stabilitas lereng. Sayangnya, pada wilayah bagian Timur ini cenderung memiliki wilayah permukiman yang padat bangunan, sehingga kekurangan daerah resapan. Kekurangan daerah resapan ini juga di picu oleh banyaknya bangunan rumah yang menggunakan plester pada halaman serta tidak adanya vegetasi di sempadan jalan.

Upaya konservasi yang tepat pada wilayah ini adalah dengan membongkar perkerasan pada halaman rumah, serta menanami dengan vegetasi agar daya resap air meningkat. Masih banyaknya halaman rumah yang menggunakan perkerasan menunjukkan bahwa masyarakat belum memahami pentingnya daerah resapan air. Oleh karenanya dalam panduan konservasi akan merekomendasikan masyarakat untuk melakukan pembongkaran beberapa perkerasan serta menggantinya dengan menanam beberapa tanaman apabila memungkinkan. Hal ini bertujuan untuk mengurangi genangan di wilayah permukiman, serta membantu air hujan untuk masuk ke tanah, sehingga bisa mengurangi gangguan stabilitas tanah di permukaan lereng.

\section{b) Wilayah bagian Tengah}

Wilayah pada bagian ini memiliki karakteristik kemiringan lereng yang tajam, upaya konservasi tidak bisa hanya mengandalkan konservasi vegetatif tetapi harus dikombinasikan dengan konservasi mekanis. Beberapa lokasi dengan kemiringan tajam di Perumahan Bukit Indah Regency sebenarnya telah dibangun talud. Akan tetapi beberapa talud kondisinya ditumbuhi rumput serta semak-semak, sehingga harus di lakukan pengecekan kembali kekuatan talud tersebut.

Meskipun telah terdapat talud di beberapa lokasi, masih terdapat lereng-lereng yang tidak bertalud, misalnya di Kampung Plasansari. Talud atau dinding penahan longsor sangat dibutuhkan pada lereng dengan kemiringan lebih dari 40\%. Masyarakat harus secara mandiri mengidentifikasi lokasi-lokasi yang memiliki kemiringan lereng terjal serta membangun dinding penahan maupun terasering. Dinding penahan ini dapat berupa perkerasan seperti batu dan semen, maupun dengan kayu dan karung. Setelah dinding penahan selesai dibangun, maka bagian-bagian yang cenderung datar dapat ditanami dengan vegetasi seperti Jati, beringin, sengon maupun tanaman produktif seperti nangka, melinjo, dan lain sebagainya. Selain itu perlu adanya pengecekan kekuatan talud secara berkala untuk memastikan bahwa talud tidak lapuk atau tergerus air hujan

\section{c) Wilayah bagian Barat}

Wilayah bagian Barat terdiri dari area pertanian dan hutan. Fungsi dari wilayah ini adalah sebagai daerah konservasi, sehingga tidak diperbolehkan membangun rumah maupun bangunan lain. Aliran air permukaan dari wilayah atas akan mengalir ke wilayah ini, untuk diteruskan ke Kali Garang. Kelestarian vegetasi pada wilayah ini sangat penting, terutama untuk menjaga agar struktur tanah tidak rusak. 
Masyarakat RW 9 harus dapat menjaga wilayah konservasi ini dari alih fungsi lahan, sehingga kestabilan lereng dapat terjaga.

Selain rekomendasi langkah konservasi pada ketiga pembagian segmen wilayah, terdapat beberapa langkah konservasi yang berlaku untuk semua wilayah. Beberapa hal yang harus dibenahi, diantaranya yaitu:

- Menanam vegetasi akar dalam disusul dengan vegetasi akar dangkal pada lokasi-lokasi yang minim tutupan vegetasi

Masih terdapat lahan yang minim tutupan vegetasi di beberapa lokasi di RW 9. Oleh karenanya, sangat penting untuk melakukan penghijauan pada lahan-lahan tersebut, sehingga daya resap air meningkat serta menjaga stabilitas tanah. Penanaman vegetasi sebaiknya menggunakan sistem strata sehingga menciptakan perakaran yang kuat untuk menjaga stabilitas tanah. Sedangkan jenis tanaman disarankan merupakan tanaman produktif sehingga dapat di panen oleh warga setempat, serta menghasilkan manfaat lebih.

- Membuat saluran drainase pada wilayah-wilayah yang tidak memiliki drainase, serta mengeruk sedimentasi agar aliran air lancar

Saluran drainase sangat penting untuk mempercepat pengeringan wilayah terhadap air hujan. Oleh karenanya pembuatan saluran drainase pada lokasi-lokasi yang tidak memiliki drainase sangat dianjurkan. Saluran drainase tidak hanya diperlukan pada lokasi padat permukiman, tetapi kawasan perkebunan serta hutan juga memerlukan saluran drainase agar air tidak tergenang dan mengganggu stabilitas tanah. Selain itu, normalisasi saluran drainase seperti pengerukan sedimentasi, menghilangkan vegetasi penutup, hingga membongkar saluran drainase tertutup merupakan salah satu usaha untuk mempercepat aliran air, sehingga tidak menggenang dan merusak struktur tanah.

\section{Kesimpulan}

Berdasarkan kondisi geografis, RW 9 menjadi salah satu wilayah di Kelurahan Srondol Kulon yang rawan terjadi longsor. Buku panduan konservasi tanah nantinya akan membahas teori-teori konservasi dengan bahasa yang mudah dimengerti oleh masyarakat, serta memberikan rekomendasi mengenai langkah konservasi yang memungkinkan untuk diterapkan di RW 9. Kondisi fisik eksisting RW 9 menunjukkan bahwa telah terdapat upaya konservasi mekanis dan vegetatif sebagai tindakan untuk mencegah bencana longsor. Akan tetapi masih terdapat beberapa hal yang perlu dibenahi, diantaranya yaitu pembangunan talud pada daerah-daerah yang rawan longsor, membongkar perkerasan halaman dan menggantinya dengan vegetasi akar dalam, melakukan penghijauan pada lahan-lahan yang gundul, mengeruk sedimentasi drainase, serta membongkar drainase tertutup agar aliran air dapat efektif masuk ke dalam saluran drainase.

\section{Ucapan Terima Kasih}

Terima kasih kepada Fakultas Teknik Universitas Diponegoro yang telah membiayai program pengabdian kepada masyarakat ini melalui Dana selain APBN Fakultas Teknik RKAT Universitas Diponegoro Tahun Anggaran 2020.

\section{Referensi}

Arifianti, Y. (2011). Buku Mengenal Tanah Longsor Sebagai Media Pembelajaran Bencana Sejak Dini. Buletin Vulkanologi dan Bencana Geologi, 6(3), 17-24.

Atmojo, S. W. (2008). Peran Agroforestri dalam Menanggulangi Banjir dan Longsor DAS. Seminar Nasional Pendidikan Agroforestry Sebagai Strategis Menghadapi Pemanasan Global di Fakultas Pertanian, UNS. Solo.

Dariah, A., Haryati, U., \& Budhyastoro, T. (2004). Teknologi Konservasi Tanah Mekanik. In U. Kurnia, A. Rachman, \& A. Dariah (Ed.), Teknologi Konservasi Tanah Pada Lahan Kering Berlereng (hal. 103126). Bogor: Pusat Penelitian dan Pengembangan Tanah dan Agroklimat.

Erfandi, D. (2013). Sistem Vegetasi dalam Penanganan Lahan Rawan Longsor pada Areal Pertanian. In Sulaiman \& et al (Ed.), Seminar Nasional Pertanian Ramah Lingkungan (hal. 319-328). Bogor: Badan Penelitian dan Pengembangan Pertanian, Kementerian Pertanian.

Idjudin, A. A. (2011). Peranan Konservasi Lahan dalam Pengelolaan Perkebunan. Jurnal Sumberdaya 
Lahan, 5(2), 103-116.

Indrayati, A. (2013). Peningkatan Ketahanan Terhadap Risiko Bencana Melalui Pendidikan Konservasi Lahan Berbasis Masyarakat di Dataran Tinggi Dieng. Jurnal Geografi, 10(2), 154-166.

Ismayani, N. (2018). Studi Pencegahan Longsor Akibat Akivitas Vulkanik Sinabung Melalui Konservasi Lahan di Kecamatan Simpang Empat Kabupaten Karo. Jurnal Kapita Selekta Geografi, 1(3), 49-54.

Kelompok 4B Proses Perencanaan. (2014). Profil Kelurahan Srondol Kulon 2014. Semarang.

Nugraha, S., RI, S., \& Utomowati, R. (2013). Model Arahan Penggunaan Lahan sebagai Upaya Mitigasi Bencana Alam melalui Pendekatan Morfokonservasi di Daerah Aliran Sungai Samin Kabupaten Karanganyar. Forum Geografi, 27(2), 115-122.

Pemerintah Kota Semarang. (2011). Rencana Tata Ruang Wilayah Kota Semarang tahun 2011-2031. Semarang.

Prihambodo, M. A. (2017). Perancangan Motion Graphic Untuk Penyuluhan Konservasi Motion Graphic Design For Soil And Water Conservation Extension To Reduce Flood And Sliding. e-Proceeding of Art \& Design, 4(3), 667-673.

Risdiyanto, I. (2011). Identifikasi Daerah Rawan Longsor. https://doi.org/10.13140/RG.2.1.4316.5684

Sharpe, C. F. S. (1938). Landslide and Related Phenomena. Columbia University Press.

SNI 8291:2016. Penyusunan dan Penentuan Zona Kerentanan Gerakan Tanah. , (2016).

Utami, O. D., Tjahjono, H., \& Sriyono. (2017). Adaptasi Masyarakat Terhadap Bencana Longsor Lahan Berdasarkan Tingkat Kerawanan di Kecamatana Banyumanik Kota Semarang. Geo Image, 6(1), 1-7.

Wahyudi. (2014). Teknik Konservasi Tanah serta Implementasinya pada Lahan Terdegradasi Dalam Kawasan Hutan. Journal Sains dan Teknologi Lingkungan, 6(2), 71-85.

Widiyanto, D. (2020). 4 Rumah Longsor, Banteng Raider Selamatkan Warga. Diambil dari krjogja.com website: https://www.krjogja.com/berita-lokal/jateng/semarang/4-rumah-longsor-banteng-raiderselamatkan-warga/

Zakaria, Z. (2009). Analisis Kestabilan Lereng Tahan. Bandung: Laboratorium Geologi Fakultas Teknik Geologi Universitas Padjadjaran. 